\title{
THE EDUCATIONAL POLICIES FOR SAFEGUARDING AND TRANSMITTING THE LANGUAGE AS AN INTANGIBLE CULTURAL HERITAGE
}

\author{
Darejan Tvaltvadze \\ Ivane Javakhishvili Tbilisi State University, Georgia \\ Irina Gvelesiani \\ Ivane Javakhishvili Tbilisi State University, Georgia
}

\begin{abstract}
Nowadays, almost all states of the world recognize the importance of the protection of cultural and language rights in sustainability of communities. This attitude is directed by globalizing processes, which strive to transform the world into a single entity via reducing differences. On the background of the globally-determined reformation, preservation of languages, traditions, values and other aspects of culture acquires the greatest urgency. Therefore, states have to pay a special attention to the protection of rights of ethnic, religious and linguistic minorities. The paper deals with the presentation of the progressive state policies as well as the projects/programs facilitating the integration of the ethnic minorities into the Georgian society with the emphasis on the general and higher education. The projects/programs aim at teaching the state language to those representatives of ethnic minorities, who have a poor knowledge or no knowledge of the Georgian language. Determination of the major challenges and outcomes of the projects/programs, discussion of some gaps, introduction of convenient opportunities of their "filling" - these are the major issues of the paper. The methodology of research includes observation, analysis and evaluation of the ongoing processes.
\end{abstract}

Keywords: cross-national, Georgia, identity, minorities, multiethnicity, policies, project.

\section{Introduction}

In 1948 "Universal Declaration of Human Rights" stated that all "human beings are born free and equal in dignity and rights. They are endowed with reason and conscience and should act towards one another in a spirit of brotherhood" (Universal Declaration of Human Rights, 1948). After several decades from the creation of this declaration, "the rights of people belonging to minority groups are violated throughout the world because cultural, religious and linguistic practices that diverge from those of the majority remain outside the control of the state" (The UN Convention on the Rights of the Child [UNCRC], 2019). Spreading a special propaganda and literacy can become the milestone of the protection of 
particular rights of ethnic, religious and linguistic minorities. It is noteworthy that literacy has often been associated with a monolingual environment. However, nowadays, it is directly linked with bilingual and multilingual societies. The contemporary rapidly developing global tendencies shift the world population from uniform to diverse, from simple to frequentative and from unilateral to multilateral. There is the necessity of moving from the traditional focus "on one dominant language and culture to a broader vision that embraces cultural and linguistic diversity and also takes account of the multimodal meaning-making opportunities... The current preferred terminology, then, is multiliteracies rather than "literacy" (Edwards, 2015, p. 77).

On the background of the rapidly growing plurality of the world societies, multiliteracies can be achieved via facilitating the multilingual education from the very childhood. It should aim at the development of every child's physical and mental abilities and promote: "The development of respect for the child's... identity, language and values, for the national values of the country in which the child is living, the country from which he or she may originate, and for civilizations different from his or her own" (UNCRC, 2019).

The paper deals with the problem of the integration of Armenian and Azerbaijanian citizens into the Georgian society. It highlights a language as an intangible cultural heritage, which can serve as a tool for the integration and development of an intercultural communication between the majority and minorities.

\section{The General Survey}

Georgia as the post-Soviet country is well-known for its multiethnicity. Representatives of different nationalities have settled its territory throughout centuries. They have always enjoyed a peaceful coexistence with the indigenous people, reflected in the preservation of language, culture, ethnic identity and even religion. During the Soviet epoch, all ethnic groups were integrated into the common life of the country. Mastering Georgian or Russian was a prerequisite of the full integration and non-marginalization (although Georgian was the state language). However, after the dissolution of the Soviet Union, the functions of Russian significantly diminished and Georgian became the dominant language of communication in the independent Republic of Georgia. Therefore, the problem of an intercultural communication appeared. The major language of education became Georgian and mastering it started being obligatory for occupying positions in governmental institutions, organizations, educational or medical centers, etc. This fact marginalized those representatives of ethnic minorities, who lived in remote towns or villages and had no knowledge or a poor knowledge of 
the state language. Their number was quite challenging. However, it decreased as a result of the migration to Armenia, Azerbaijan, Greece, Russia, etc.

Nowadays, "the ethnic minority groups are predominantly resided in two regions of Georgia as well as in capital of the country, while Azeri population is living in Kvemo Kartli region and Armenians are consolidated in SamtskheJavakheti” (Gorgadze, 2016, p. 12). "About 13\% of the population of Georgia does not indicate the State language as native and $74 \%$ of the Azerbaijani population and 51.3\% of Armenians cannot speak Georgian fluently or cannot speak it at all” (Gabunia, 2017, p. 43). Georgia's government sets certain goals for the Armenians' and the Azerbaijanis' full integration into the Georgian society via spreading multiliteracies. The major steps have been taken after signing the European Charter for Regional or Minority Languages of the Council of Europe (1998) and after the ratification of the Framework Convention on National Minorities of the Council of Europe (2005). Since 2009 the government has been putting an accent on the promotion of a high-quality education, which has long been at the forefront of civil rights and has had a "crucial role in building the right $21^{\text {st }}$ century skills and competences" (Assessment of Key Competences in Initial Education and Training: Policy Guidance). The latter comprise mastering languages and acquiring the social and civil competences that refer to "the development of skills and values necessary for integration into civilian life, such as constructive collaboration, problem solving, critical and creative thinking, decision making, tolerance, respect for others' rights, and recognition of democratic principles" (Assessment Document on the Implementation of the National Concept for Tolerance and Civic Integration and Action Plan 2009-2014, 2014). The contemporary challenging epoch requires the promotion of a highquality education at all levels of knowledge-acquisition. In case of non-Georgian citizens, the reformation covers the general and higher education.

\section{The General Education + BA Level}

"In those States in which ethnic, religious or linguistic minorities or persons of indigenous origin exist, a child belonging to such a minority or who is indigenous shall not be denied the right, in community with other members of his or her group, to enjoy his or her own culture, to profess and practice his or her own religion, or to use his or her own language" (UNCRC, 2019). Moreover, she/he must be given an ultimate possibility to study the state language for circulating freely in the society.

Georgia, like many other post-Soviet countries, has shared these statements and has made several attempts for the establishment of the successful multicultural policies. Among them was the testing of the model of the multilingual education within the framework of Multilingual Education Pilot 
Project, which was implemented in 2006-2008 at 12 schools of Georgia. "During the Pilot Project, 12 research methods and instruments have been devised and implemented. Conclusions from the data analysis have been drawn, and recommendations for a broader implementation of multilingual education in Georgia have been provided” (Grigule, 2009, p. 4). As a result, the curriculum project for teaching Armenian as well as Azerbaijani as a native language was developed via the participation of the Armenian and the Azerbaijani experts. "In 2008, the Ministry of Education and Science developed the "National Minority Integration through Multilingual Education” document” (Tabatadze, 2015, p. 98). Later the Program "1+4" / "1+4" Scheme was created. It offered "simplified procedures for the representatives of ethnic minorities, inter alia, Armenians and Azerbaijanis to enroll in higher education institutions of Georgia by passing only one exam in their native language, with one year in Georgian language training followed (in case of obtaining of 60 credits) by four years of undergraduate studies in a program of their own choice” (Third Report submitted by Georgia Pursuant to Article 25, 2017).

The initial stage of " $1+4$ " Scheme is "Georgian Language Training Educational Programme", which considers learning a new language via learning a new culture. Culture and cultural features are taught not only implicitly, but explicitly - through the explicit topics of discussion during classroom activities. Learners get acquainted with the Georgian literary and folklore masterpieces and get information (via giving clues and background information) on the objects and ideas that differ from their cultural reality.

The implementation of the Program " $1+4$ " has resulted in a drastic increase of the number of students representing different minority groups. According to the statistical data, 2919 representatives of ethnic minorities have been enrolled in one-year program of Ivane Javakhishvili Tbilisi State University (TSU) during 2010 - 2018. Approximately 2000 students successfully passed the program. The greatest majority of them became the students of TSU and achieved good results during BA studies. More precisely, in 2010156 entrants were enrolled in oneyear preparatory program. In 2018 their number reached 300. Table 1 shows more precise dynamics:

In 2015 the Decree of the Government of Georgia (№ 1740) “On Approval of the State Strategy for Civic Equality and Integration and Action Plan for 20152020" highly evaluated the usefulness and importance of the Program " $1+4$ ": "The current preferential policy (the so-called " $1+4$ " scheme) has made a significant contribution to improving access to higher education for ethnic minorities, respectively, the policy will be continued and further refined... It is important to involve graduates educated under the preferential scheme in the teaching process at non-Georgian language schools, and also to develop and fund such university training programs, which are aimed at improving the quality of 
SOCIETY. INTEGRATION. EDUCATION

Proceedings of the International Scientific Conference. Volume V, May $22^{\text {th }}-23^{\text {th }}, 2020.570-578$

universal education in non-Georgian schools, teaching native and state languages, as well as employing young representatives of ethnic minorities in priority areas in Georgia” (Decree of the Government of Georgia, 2015).

Table 1 The statistics of students' enrolment in one-year preparatory program of TSU during 2010-2019

\begin{tabular}{|c|c|}
\hline Teaching year & $\begin{array}{c}\text { The number of the students of one-year } \\
\text { preparatory program }\end{array}$ \\
\hline $2010-2011$ & 156 \\
\hline $2011-2012$ & 256 \\
\hline $2012-2013$ & 314 \\
\hline $2013-2014$ & 284 \\
\hline $2014-2015$ & 264 \\
\hline $2015-2016$ & 247 \\
\hline $2016-2017$ & 258 \\
\hline $2017-2018$ & 296 \\
\hline $2018-2019$ & 300 \\
\hline
\end{tabular}

This extract is in tune with the major outcomes of DIMTEGU - the progressive project, which was initiated and coordinated by TSU in 2012-2016. The major goal of DIMTEGU was the adherence to the principle of equality via supporting the multilingual education reform in Georgia and the Ukraine through the multistage activities. Its initial focus was a considerable increase of the number of teachers in some regions of Georgia, especially, in the areas compactly settled with the national minorities, where the introduction of the methodology of the multilingual education and its institutional promotion was highly recommended. DIMTEGU planned and successfully carried out some important activities:

1. The intensive training of regional teachers for the reinforcement of the already-existed "resource";

2. The development and implementation of the new BA Program in Multilingual Education (Primary Education);

3. The creation of one-year program of multilingual education;

4. Translation of " 20 textbooks on multilingual education... in the Georgian and Ukrainian languages. 200 copies published in each language” (DIMTEGU).

It is noteworthy that the teachers' professional development trainingprogram comprised the cycle of activities divided into three phases:

1. The training program "Bilingualism and Bilingual Education Principles; Content and Language Integrated Learning (CLIL)" that aimed at the improvement of the performance of the teachers of the 
primary grade at non-Georgian schools. The training was conducted in five cities resided by non-Georgian population and comprised 45 contact hours;

2. The extra second cycle of the training "Foundations of Multilingualism and Multilingual Education; Content and Language Integrated Teaching" - implemented in cooperation with the program "Learn Georgian" funded by the Reserve Fund of President of Georgia. The training program consisted of 20 contact hours;

3. The extra third session "Content and Language Integrated Learning (CLIL)".

In total, the teachers' professional development training-program trained 300 in-service teachers of the regional schools. The trainers were the Georgians trained abroad.

One of the most important outcomes of DIMTEGU was the piloting and implementation of the BA Program in Multilingual Education (Primary Education), which was prepared under an active supervision and participation of the EU partners. Nowadays, the program is ongoing and offers two major modules:

1. A teacher of the Armenian language and literature / A teacher of the Georgian language and literature (the second language); A teacher of mathematics and natural sciences (the $1^{\text {st }}-4^{\text {th }}$ grades);

2. A teacher of the Azerbaijani language and literature / A teacher of the Georgian language and literature (the second language); A teacher of mathematics and natural sciences (the $1^{\text {st }}-4^{\text {th }}$ grades).

The BA Program in Multilingual Education welcomes entrants of different nationalities. However, it is mainly focused on the ethnic minorities (the Armenians and the Azerbaijanis), which are compactly settled in the southern part of Georgia, where the lack of subject teachers and the teachers of the Georgian language is considered as one of the biggest challenges. The implementation of this BA program is one of the most effective ways of the solution of the problem it aims at the preparation of multilingual teachers for the primary schools, especially, for the regions settled with the ethnic minorities.

\section{Integrated BA and MA Educational Program for the Preparation of Multilingual School Teacher}

Besides developing the BA Program, the team of DIMTEGU started the creation of the MA Program in Multilingual Education. However, the resolution of the Government of Georgia (N.68/20.02.2015) on "Teachers' Training, Professional Development and Career Growth" totally changed the system of a teacher's education. The resolution initiated the transformation of BA and MA 
programs into a new graduate program and the preparation of one-year teachers' training program. Therefore, the team of DIMTEGU started the creation of "Oneyear program of multilingual education”, which aimed at the training of bilingual teachers of non-Georgian schools in several subjects. The envisaged structure of the program was the following: Compulsory educational courses (40 ECTS); Compulsory pedagogical practice (10 ECTS); Elective modules - Subject teaching methods in: Mathematics, Physics, Chemistry, Biology, History, Geography, Social Education, Georgian as a second language, Armenian as a native language, Azeri as a native language, English as a foreign language.

The major challenge of the envisaged program was raising the awareness of an intercultural dialogue and equality as well as the increase of the quality of a teacher's education, which is generally "among one of the topical keywords in political discourse, scientific research and implementation process of teaching practices” (Bethere, Pavitola, \& Usca, 2016, p. 263).

It is noteworthy that the recent educational reform demanded the formation of 5-year "Integrated BA and MA educational program for the preparation of multilingual school teachers", which would comprise 300 ECTS. Therefore, the creators of "One-year program of multilingual education" will start its readjustment and the preparation of the integrated BA and MA educational program on the basis of already worked-out strategies.

Finally, it is noteworthy that the above-mentioned projects/programs ("1+4" Program; DIMTEGU) can be treated as catalysts of the multilingual reform stipulated by plurality and global tendencies. The projects reflect the structural changes initiated by the government of Georgia. The changes are oriented to the employment of postgraduates, because non-Georgian schools are obliged to employ the multilingual teachers, who graduate from the above-mentioned programs. At the same time, schools are required to contribute to their teachers' attendance of teacher training programs, especially, in the direction of CLIL.

\section{Conclusions}

Georgia as the small multiethnic post-Soviet country has faced numerous challenges and transformations for ensuring democracy and equality within a democratic society. Nowadays, it maintains independence and a peaceful coexistence of the representatives of different nationalities residing on its territory. The Georgians have always respected other nation's values, language, culture, ethnic identity and religion. The same respect is felt in the contemporary policies directed towards the safeguarding and transmitting languages as the samples of an intangible cultural heritage. The multilingual and intercultural education is the foundation of these processes. The paper deals with the presentation of the governmental policies as well as the projects/programs facilitating the integration 
of the ethnic minorities into the Georgian society with the emphasis on the general and higher education. The paper presents certain insights and makes specific proposals regarding a proper implementation of the innovative programs. We believe that the adherence to the recommendations will ensure a successful development of the policies directed towards the integration of the ethnic minorities. Georgia's policies can become useful for other post-Soviet countries, which strive to implement the western-oriented strategies.

\section{Summary}

Georgia is marked by the ethnic diversity and plurality. However, coping with the implementation of the multilingual educational strategies into the post-Soviet soil is associated with the ceaseless Herculean efforts and mastery. The paper highlights the governmental regulations and modern projects focused on the educational reformation and the strategies of the implementation of the multilingual education, which succeed in two major directions. On the one hand, they strive to facilitate the safeguarding of minority languages via an intensive teaching of Armenian and Azerbaijani at higher educational institutions (BA Program in Multilingual Education (Primary Education)). On the other hand, they ensure ethnic minorities' adaptation to the labor market and provision of their employment opportunities via using different ways of teaching the state language (the teacher-training courses, Program " $1+4$ ", BA Program in Multilingual Education, etc).

However, taking a closer look at the activities initiated by the projects/programs reveals certain gaps, for instance, the teachers' professional development trainings supervised by DIMTEGU were carried out by the Georgian specialists trained abroad. We believe that the involvement of foreign trainers during similar professional development trainings will be crucial for achieving better results, especially, in the fields of CLIL, multilingualism and multilingual education, which are absolute novelties for Georgia's educational space.

The program " $1+4$ " seems quite beneficial for non-Georgian citizens. However, the gained benefits will be more valuable if during studies, the learners will be distributed according to sectors in order to study the concepts, terminological units and vocabulary specific to the branches of their further BA studies. Moreover, it is preferable to create the Centers of Academic Support at the faculties of the university in order to ensure non-Georgian students' assistance in a complete involvement in academic processes as well as in the university's scientific activities via facilitating their participation in different conferences, workshops, literary contests, etc. Moreover, we believe that "BA Program in Multilingual Education” lacks an international experience of students. A short / long term internship abroad should deepen each learner's knowledge of the methods and strategies of teaching in bilingual / multilingual classes.

\section{References}

Assessment Document on the Implementation of the National Concept for Tolerance and Civic Integration and Action Plan 2009-2014. (2014). Retrieved from http://www.minoritiesnetwork.org/wp-content/uploads/2014/10/doc329.pdf

Bethere, D., Pavitola, L., \& Usca, S. (2016). Building Pedagogical Relationships in Diverse Educational Environments. Journal of Teaching and Education, 05(01), 263-274. 
SOCIETY. INTEGRATION. EDUCATION

Proceedings of the International Scientific Conference. Volume V, May $22^{\text {th }}-23^{\text {th }}, 2020.570-578$

Commission Staff Working Document. (n.d.). Assessment of Key Competences in Initial Education and Training: Policy Guidance. Retrieved from http://csdle.lex.unict.it/ Archive/LW/Data\%20reports\%20and\%20studies/Reports\%20and\%20\%20communicati on\%20from\%20EU\%20Commission/20121128-012143_SWD-371_2012_enpdf.pdf

Decree of the Government of Georgia № 1740 August 17, 2015. (2015). On Approval of the State Strategy for Civic Equality and Integration and Action Plan for 2015-2020. Retrieved from http://smr.gov.ge/Uploads/esen_55b90432.pdf

DIMTEGU. (n. d.). Retrieved from http://dimtegu.tsu.ge/

Edwards, V. (2015). Literacy in Bilingual and Multilingual Education. In W.E. Wright, S. Boun \& O. Garcia (Eds.), The Handbook of Bilingual and Multilingual Education (pp. 75-91). The USA: John Wiley \& Sons, Inc.

Gabunia, K. (2017). The Significance of Multilingual Education in the Context of Integration of Minorities into Society. International Journal of Multilingual Education, 10, 43-51.

Gorgadze, N. (2016). Rethinking Integration Policy - Dual Ethnic and Cultural Identity. International Journal of Multilingual Education, 8, 6-31.

Grigule, L. (2009). Shaping the Multilingual Learning Environment: The Case of Multilingual Education Pilot Project in Georgia. Journal of Teacher Education for Sustainability, 11, 50-64.

Tabatadze, Sh. (2015). Factors Influencing the Effectiveness of Bilingual Educational Programs: The Prospects of Pilot Programs in Georgia. Sino-US English Teaching, 12(2), 93-109.

The UN Convention on the Rights of the Child. (2019). Retrieved from https://www.crin.org/ en/home/rights/convention/articles/article-29-aims-education

Third Report submitted by Georgia Pursuant to Article 25, Paragraph 2 of the Framework Convention for the Protection of National Minorities. (2017). Retrieved from https://rm.coe.int/third-state-report-georgia/168075fc5e

Universal Declaration of Human Rights. (1948). Retrieved from http://www.un.org/ en/universal-declaration-human-rights/index.html 